Reprod. Nutr. Dévelop., 1988, 28 (2 B), 409-422.

\title{
Photoperiodic and melatonin treatments for the control of seasonal reproduction in sheep and goats
}

\author{
P. CHEMINEAU, J. PELLETIER, Y. GUÉRIN, G. COLAS, J. P. RAVAULT, \\ G. TOURÉ, G. ALMEIDA, J. THIMONIER, R. ORTAVANT \\ with the technical assistance of Agnès DAVEAU, Françoise MAURICE, Odile MOULIN, \\ D. CHESNEAU and B. MIRMAN
}

Physiologie de la Reproduction, I.N.R.A. Nouzilly, 37380 Monnaie, France.

Summary. The control of seasonal reproductive activity in sheep and goats in open sheds, needs extra-light (E) during the photosensitive phase (equivalent to long days, $L D$ ), followed by treatment with melatonin (equivalent to short days, SD).

In autumn-born lle-de-France or Lacaune ram lambs, 2 months of $E$ followed by decreasing daylength for 90 days, advanced onset of the first breeding season by allowing males to reach their maximum testis volume and sperm production earlier than for untreated ram lambs. Substitution of decreasing daylength with melatonin implants allowed a transient increase in testis volume.

Adult lle-de-France rams maintained under short light rhythms with 2 month-period, demonstrated, during at least 2 consecutive years, a testis volume equivalent to that observed during the normal breeding season. These light-treated rams produced, during non-breeding season, spermatozoa in the same quantity and quality as during the normal breeding season.

In anovulatory out-of-season dairy goats, E treatment was demonstrated to be necessary before melatonin treatment and melatonin to be necessary after $E$ treatment to stimulate oestrous and ovulatory activities. Stimulation of the anovulatory females by the introduction of treated males (« male effect $)$ ), appeared to be necessary to obtain maximum stimulation of the treated females. Two months of $E$, followed by melatonin treatment (daily injection or drenching or subcutaneous implants) allowed cycles with ovulation to be maintained for more than 2 months. Although effective for control of outof-season reproductive activity, melatonin slighlty decreased milk production when applied soon after kidding.

So, total control of reproduction in sheep and goats by manipulation of photoperiod in open sheds and melatonin treatments appears feasible in both sexes.

\section{Introduction.}

Under normal variations of daylength in mid-latitudes, sheep and goat females demonstrate very repeatable and clear-cut anovulatory and anoestrous periods from the end of winter to mid-summer. Males show important variation in behavioural and spermatogenetic activities. Photoperiod is the main cue which 
controls these seasonal patterns (see reviews : Ortavant et al., 1985 ; Hansen, 1985 ; Pelletier et al., 1987). Long days (LD) are reported to be inhibitory and short days (SD) stimulatory to sexual activity (Lincoln and Short, 1980 ; Karsch et al., 1984). However, under unchanging stimulatory photoperiods, permanent sexual activity cannot be sustained (Ortavant et al., 1964 ; Ducker et al., 1973).

Control of sexual activity by light has been used in both sexes. Generally, a priming period of natural or artificial LD is given before either artificially decreasing daylengths or SD. These light treatments, although efficient to induce reproductive activity, require intensive management and are expensive to apply because they require light-proof buildings.

Recent progress has opened promising perspectives for the control of reproductive activity. Our aim, in this paper is to review the recent advances of our laboratory in this area.

\section{I. - General principles of the light treatments.}

1) Alternating between $L D$ and $S D$ were considered as a key to achieve control of sexual activity : LD appear necessary to restore the inductive effect of $\mathrm{SD}$ at the end of winter and to prevent refractoriness to photoperiodic stimulation (Yellon and Foster, 1985).

2) Timing of illumination during the circadian rhythm was demonstrated to be more important than the duration of the light phase (Ortavant, 1977 ; Pelletier et al., 1981; Thimonier, 1981; Pelletier and Thimonier, 1987). A LD is characterized by a period of illumination for 15-18 $\mathrm{h}$ after dawn. This suggested the possibility of using extra-light (E) during this photosensitive phase, instead of real LD. Real LD will be indicated here as LD and mimicked LD as " LD ".

3) Effects of SD could be mimicked by melatonin administration (injection, ingestion or slow release devices ; Kennaway et al., 1980, 1982 ; Arendt et al., 1983 ; Karsch et al., 1984 ; Arendt, 1986 ; Poulton et al., 1987). In our conditions, a SD is a day when daylength is $8 \mathrm{~h}$ or less, or a day when melatonin is administrated at the appropriate time. Real SD will be indicated here as SD and mimicked SD as « SD ».

The objectives were to develop treatments that are easily applicable under farm conditions (i.e. in open sheds) and to obtain coincident high spermatogenetic activity in males and cyclical ovulatory and oestrous activities in females.

\section{II. - Control of spermatogenetic activity in the male.}

Spermatogenetic activity was determined by measuring testis volume of males, weekly or twice monthly by comparative palpation with an orchidometer (Oldham et al., 1978). When measured, sperm production was measured by collecting four ejaculates weekly, for 9 consecutive weeks using an artificial vagina. In young lle-de-France ram lambs, sperm collection took place after 220 
days of age (mid-May to mid-July). In adult lle-de-France rams, sperm collection was from mid-March to mid-May, the period of deep sexual rest normally experienced by untreated rams.

The treatments were applied mainly to Ile-de-France rams. As previously demonstrated in this breed, photoperiodic changes induced acute variation in spermatogenetic efficiency in the adult ram (Ortavant, 1961) and also significantly modify peripuberal testis growth and puberty (Alberio, 1976). Treatments were also applied to Lacaune ram lambs, a breed for which the breeding season is less well marked.

\section{1) Young rams.}

The objective was to advance puberty and, consequently, the propitious time for semen collection during the first year of life of young rams.

The light-treatment applied on October-born ram lambs consisted of 2 months during which $1 \mathrm{~h}$ of $\mathrm{E}$ was given 16 to $17 \mathrm{~h}$ after a fixed dawn, immediately followed by 3 months during which daylength was decreased gradually from 16 to $8 \mathrm{~h}$ (fig. 1). The light treatments always started in January when the ram lambs were in their third month of life. They were applied, for experimental purpose, in light-proof buildings, but the first part of the treatment could easily be achieved in open sheds. Control rams were always subjected to natural changes in daylength prevailing in France (latitude 45 or $47^{\circ} \mathrm{N}$ according to the experiment). In lle-de-France ram lambs a supplementary experiment was conducted to determine if it was possible to substitute the second part of the treatment (decreasing days) by two successive subcutaneous implants of melatonin inserted 65 days apart.

In light-treated lle-de-France ram lambs, a significant increase in testis growth rate occurred from end-January to March (80 to 170 days old), compared to control rams (fig. 1 ; Colas et al., 1987). Afterwards, from March to May, testis volume of treated males continued to increase while testis volume of control rams remained almost constant, as usual during sexual rest (Alberio, 1976). At the end of the treatment (begining of June), testis volume of light-treated ram lambs was twice that of control ram lambs (198 vs $105 \mathrm{ml}, \mathrm{P}<0.01)$.

Lacaune ram lambs, treated in an artificial insemination center, demonstrated a significant, but less dramatic, increase in testis volume compared to control ram lambs (Colas et al., 1987). However, the percentage of rams from which semen was collected during their first year was slightly increased (Control : $57 \%$ vs Light : $71 \% ; \mathrm{P}<0.10$ ) and the total number of artificial insemination doses produced was significantly increased $(29.5 \pm 31.8$ vs $63.3 \pm 36.4$; mean \pm SEM ; $P<0.05$ ) by treatment (A.I. Centers of Roquefort area, unpublished results). So, even in a breed considered to have a low sensitivity to light changes, puberty depended, at least in part, on photoperiod.

According to preliminary results, melatonin treatment had a positive effect on testis volume, at least during the first month following insertion of the implant. The highest sperm production was found in males exposed to decreasing daylength, then melatonin-treated ram lambs and finally control ram lambs. These 


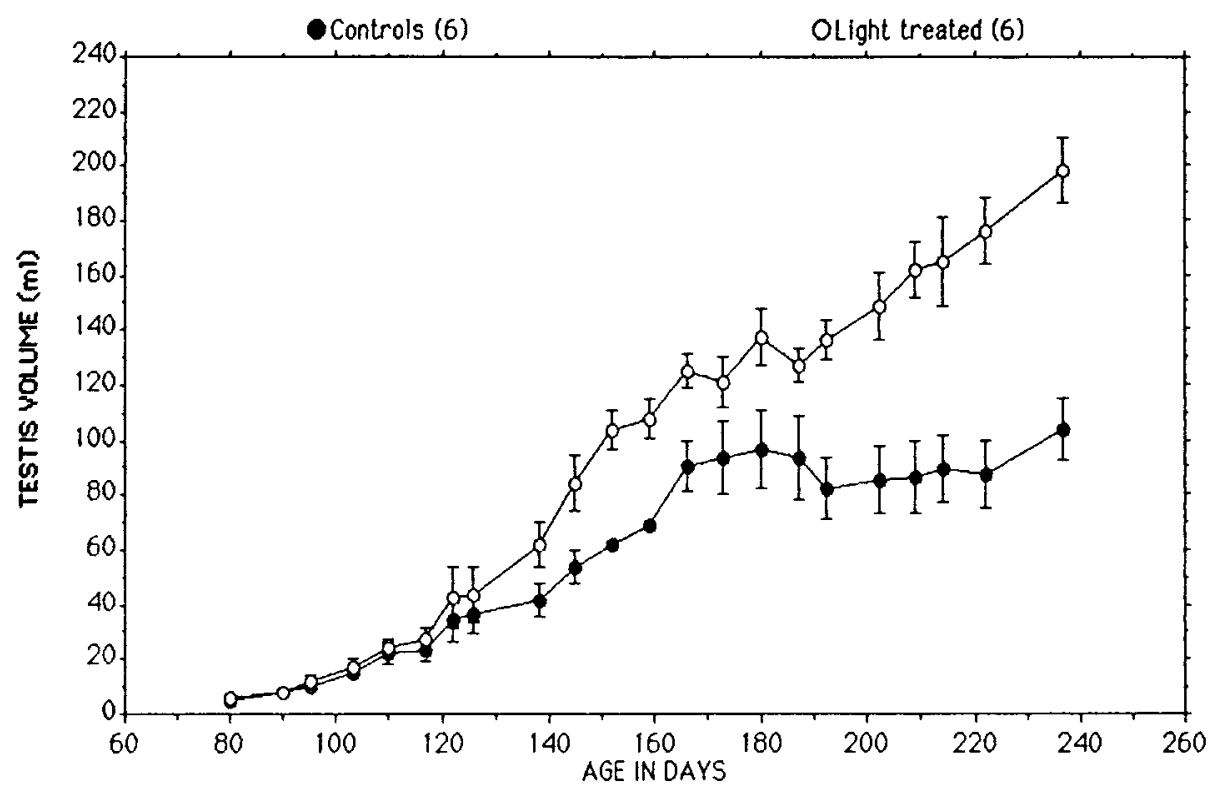

CONTROLS:

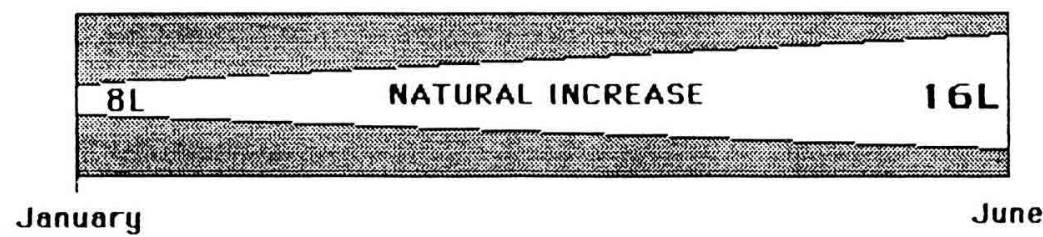

\section{LIGHT-TREATED:}

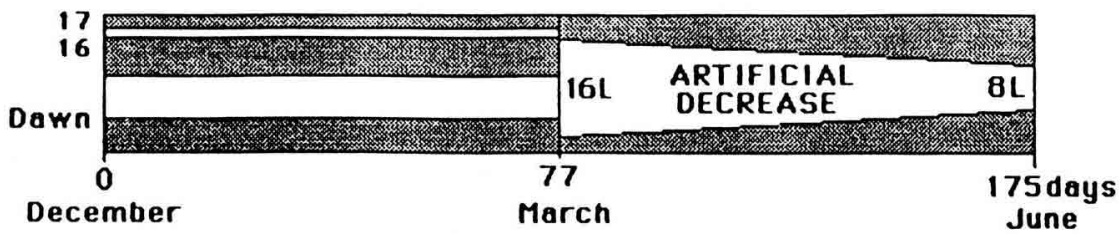

FIG. 1. - Testis weight ( $\mathrm{m} \pm$ s.e.m.) in lle-de-France light-treated and control ram lambs in response to photoperiodic treatments (from Colas et al., 1987).

results confirmed treatment effects on testis volume (G. Touré, G. Almeida, Y. Guérin and $G$. Colas, unpublished results). The difference between light-treated and melatonin-treated ram lambs could be attributed to the delay of appearance of refractoriness to SD in the males submitted to decreasing daylengths (Malpaux et al., 1988).

However, after the end of the treatments, when rams were returned to natural daylength, testis volume of previously treated ram lambs decreased rapidly 
while testis volume of control ram lambs began to increase as usual during spring/summer (Colas et al., 1987).

Consequently, an earlier stimulation of spermatogenesis in autumn-born lambs is induced by a "LD " treatment (E) during the pre-puberal period, followed by a «SD " treatment (decreasing daylength or melatonin). So, advancing onset of the first "Breeding Season " and increasing the sperm production were feasible with such treatments. This could shorten, by one year the intergeneration interval of breeding schemes by allowing progeny testing of treated males during their first year of life. Moreover, advancing the breeding season by one year, will allow a $25 \%$ increase in the reproductive life of treated rams.

\section{2) Adult rams.}

In adult rams, the objective was to obtain a permanent non-seasonal breeder by preventing the usual decrease in spermatogenetic activity, that normally occurs from mid-winter until the next summer.

The photoperiodic treatments applied in Ile-de-France adult rams, consisted of rapid shifts between SD and LD (" Short light rhythms ") to prevent the appearance of refractoriness to stimulatory SD (Pelletier et al., 1985; Almeida and Pelletier, 1988). Two types of light cycles were applied, each one with a twomonth period (fig. 2) ; Pelletier and Almeida, 1987) :

- One month of $8 \mathrm{~L}: 16 \mathrm{D}$ followed by one month of $16 \mathrm{~L}: 8 \mathrm{D}$;

- One month of $8 \mathrm{~L}: 16 \mathrm{D}$ followed by one month of $7 \mathrm{~L}: 8 \mathrm{D}: 1 \mathrm{~L}: 8 \mathrm{D}$ (1 hour of E given 15 to $16 \mathrm{~h}$ after dawn).

Testis volume for rams in treated groups began to increase after 4 to 6 months and reached maximum values similar to those normally found at the onset of the breeding season (June-July). Afterwards, in both treatments, testis volume was maintained at its maximum for at least two years. During the normal period of sexual rest (i.e., January to June when testis volume in untreated animals, was less than $200 \mathrm{ml}$ ), the light treated rams had testis volumes of about $300 \mathrm{ml}$ (fig. 2 ; Pelletier and Almeida, 1987). When compared to sperm production of lle-de-France rams maintained under natural-simulated 6 months of increasing daylength and 6 months of decreasing daylength (Colas et al., 1985), rams from the first group (fig. 3) produced $7.4 \times 10^{9}$ sperm per ejaculate, which is similar to that observed during the "sexual season " $\left(6.4 \times 10^{9}\right)$ and much higher than observed during the "non sexual season » $\left(2.6 \times 10^{9} ;\right.$ fig. 3$)$. The average percentage of abnormal spermatozoa produced by short-light-cycle treated rams $(6.5 \%)$ followed the same trend. It was close to the percentage of abnormal spermatozoa produced by rams during the "sexual season 》 $(11.5 \%)$ but much lower than the percentage observed during the " non-sexual season " $(22.1 \%$; G. Almeida, G. Touré and J. Pelletier, unpublished results).

So, non seasonal rams, producing large quantities of high quality spermatozoa can be obtained by alternating between « LD » and « SD ».

In the Alpine he-goat, preliminary data indicate that such "Short light rhythms " also allow maintenance of testis volume and sperm production characteristic of the normal sexual season (J. A. Delgadillo and P. Chemineau, unpublished results). 


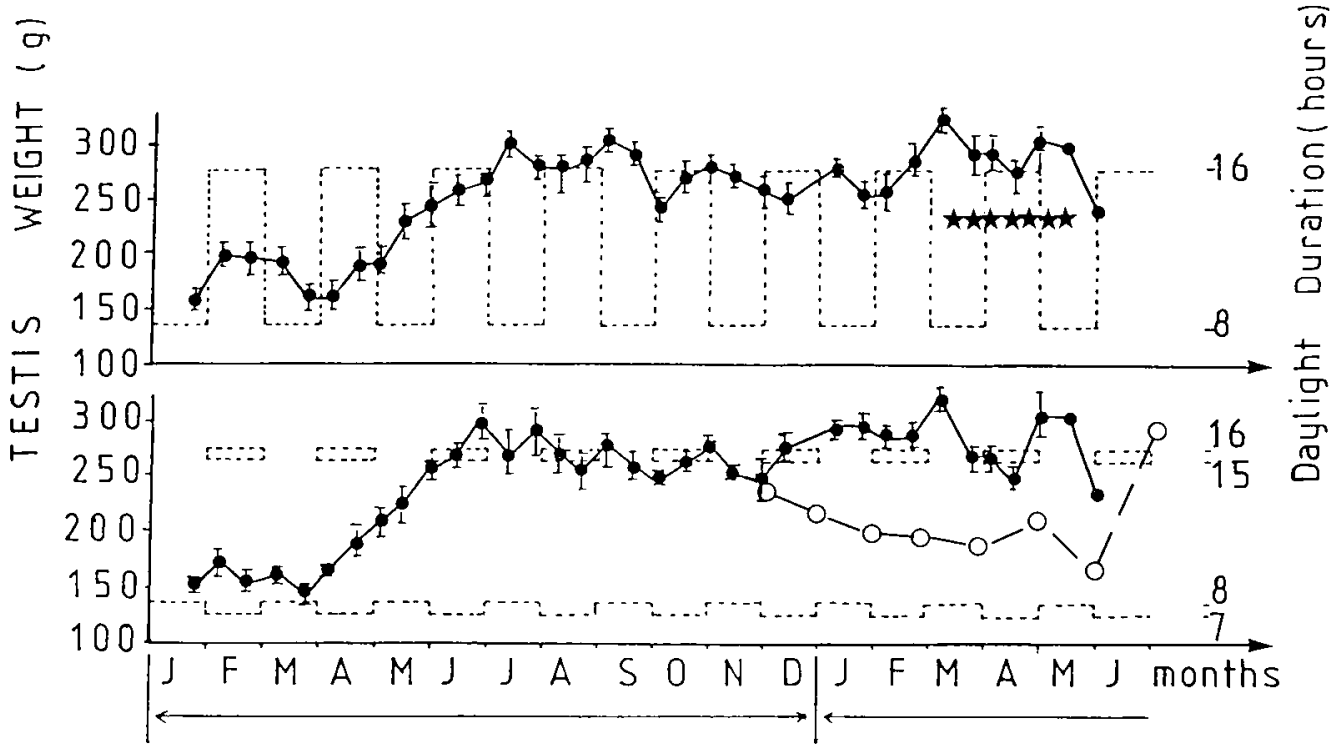

FIG. 2. - Testis weight ( $\mathrm{m} \pm \mathrm{s.e.m.}$ ) in $6 / \mathrm{le}$-de-France adult rams, submitted to two different light regimens (dashed lines represent daylight duration). Adapted from Pelletier and Almeida (1987), by courtesy of J. Reprod. Fert. $\star=$ period of semen collection ; - = testis weight of untreated rams.

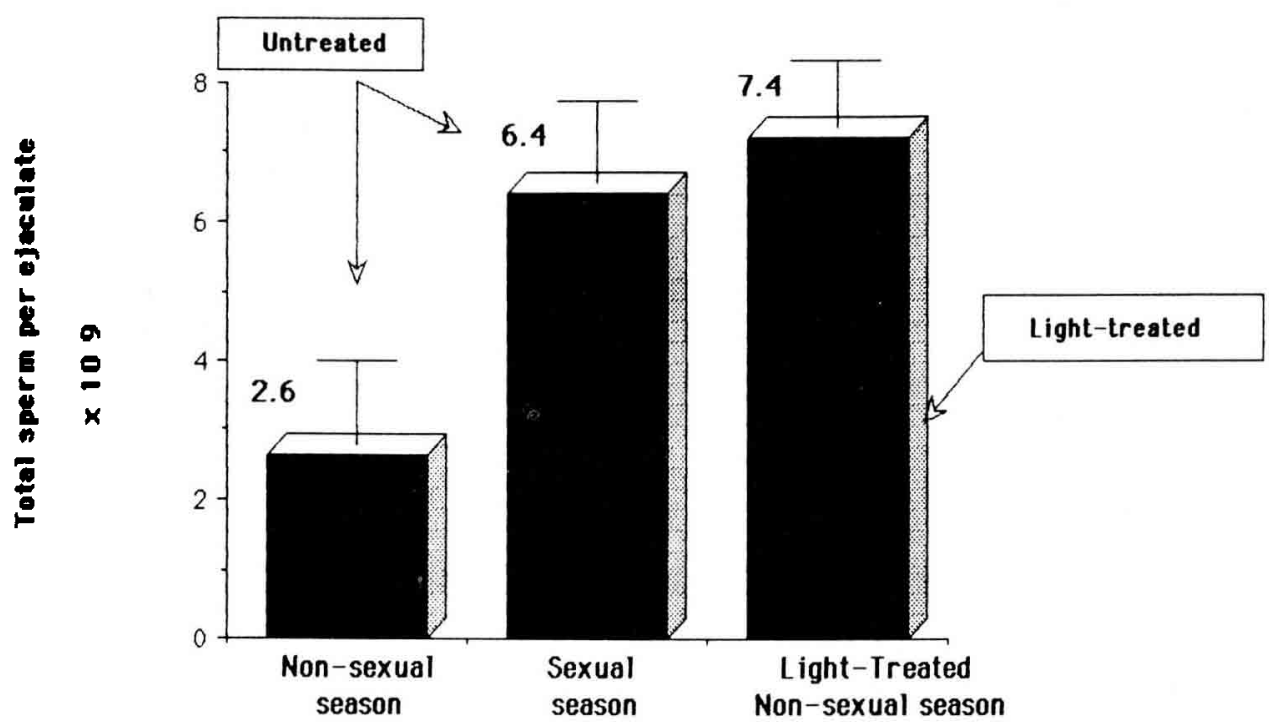

FIG. 3. - Average number of spermatozoa per ejaculate in Ile-de-France light-treated adult rams (right), compared to untreated rams during the "sexual season " (middle) or "non sexual season " (left). Values for untreated ram are adapted from Colas et al. (1985) ; values for lighttreated rams are from G. Almeida, G. Touré and J. Pelletier (unpublished data). 
Present research is to adapt these results to management of rams and hegoats kept in open sheds. Experiments presently being conducted involve the following protocols : 1) lle-de-France rams receiving one hour of E $23: 00-00: 00$ GMT, during one month out of two and 2) Alpine he-goats receiving a melatonin implant one month out of two. In the first case we hypothesized that rams " read " SD after cessation of $E$ and in the second case we hypothesized that hegoats « read " LD after removal of melatonin implants.

\section{III. - Control of female reproductive activity.}

The use of melatonin in female sheep and goats was reported to advance onset of the annual breeding season by about one month. When applied too early in the year (before the summer solstice), females did not have an earlier onset of sexual activity compared to the untreated animals (Symons et al., 1987). The objective of the present study was to obtain out-of-season (April to July) oestrus cycles and ovulations using light and melatonin treatments.

We hypothesized that ewes and does do not respond early to melatonin treatment because they had not been exposed to LD during the winter months. If true, they could also perceive the cessation of "LD " treatment during winter months as SD, in spite of the natural increase in daylength. Consequently, melatonin treatment would not be necessary. These two ideas were tested. The first experiment determined the interval between onset of SD and onset of ovulatory activity. The second experiment determined if a « LD » treatment was necessary before melatonin treatment and if melatonin treatment was necessary after a "LD 》 treatment. The third experiment tested the efficiency of three different ways of melatonin administration. As we used the "male effect " (Chemineau, 1987) to induce and synchronize ovulations in treated females in the second and third experiments, we tested in the fourth experiment if male stimulation was necessary for the ovulatory activity. Finally, as trials were performed involving dairy goats, we measured the effects of melatonin treatment on milk production.

In all experiments ovulatory activity was assessed by measuring plasma progesterone levels (Terqui and Thimonier, 1974) in blood samples collected once or twice weekly. Oestrous behaviour, when measured, was detected twice daily with vasectomized males.

1) Interval between onset of SD and onset of ovulatory activity (P. Chemineau and J. Thimonier, unpublished results).

Eight adult Alpine Saanen does and eight adult Ile-de-France ewes were placed into light-proof buildings and subjected during one year to alternating periods of 3 months of 16L : 8D (LD) and 3 months of 8L : 16D (SD). In both species ovulatory activity was entrained by light changes: two periods of ovulatory activity were observed during the experimental year. The average interval between photoperiodic shifts from LD to SD (at 8 and 32 weeks) and the 
onset of ovulatory activity was respectively, 74 days $( \pm 1)$ and 85 days $( \pm 2)$ for the doe and 53 days $( \pm 4)$ and 52 days $( \pm 4)$ for the ewe. Consequently, in the subsequent treatments, the expected time for onset of ovulatory activity after the beginning of SD treatment is about 80 days in the Alpine Saanen doe and 50 days in the lle-de-France ewe.

2) Is a " $L D \|$ treatment necessary before a melatonin treatment? Is melatonin treatment necessary after a " $L D \|$ treatment? (Chemineau et al., 1986).

These two hypotheses were tested simultaneously using a $2 \times 2$ factorial experimental design involving presence or absence of a «LD » treatment, followed or not, by a melatonin treatment. All animals 4 groups of 8 females each) were maintained in open sheds and were Alpine Saanen dairy goats which kidded during the experiment (end of February to onset of March). One group (control-control : $\mathrm{CC}$ ) received no treatment ; one group (E-control : $\mathrm{EC}$ ) received during 60 days, $2 \mathrm{~h}$ of $\mathrm{E}$ from 16-18 h after a fixed dawn; one group (controlmelatonin : CM) received during 100 days after March 20, $2 \mathrm{mg}$ of melatonin delivered daily by intra-muscular injections at $03: 00 \mathrm{pm}$; the last group (Emelatonin : EM) received successively the two preceding treatments (fig. 4). In all groups, males treated as EM females, begining one month earlier, were introduced on May 30, or 70 days after the onset of melatonin treatment. This was to induce synchronized ovulations by the " male effect".

No ovulation was detected in any group before introduction of males. Melatonin treatment advanced significantly the response to the " male effect $"$ in all groups. $E$ treatment had no effect on the response. When data from the $C M$ and EM groups were pooled, the interval from introduction of males to $1^{\text {st }}$ ovulation was 2.3 days compared to 6.1 days for $C C+E C$ groups $(P<0.001)$. Ovulatory cyclicity persisted longer in EM females compared to other groups : 2.5 months after the "male effect" 6 of 8 EM females were still cycling compared to 1 of 8 in the CM and none in the CC and EC groups. All females $(8$ of 8 ) in the EM group experienced at least, two consecutive oestrus compared to 5 of 8 in the EC and CM groups and to 2 of 8 in the CC group.

We concluded therefore, that "LD " treatment is necessary before melatonin treatment to establish ovulatory cyclicity and maximum expression of oestrous behaviour. In the same way, melatonin treatment was necessary after "LD " treatment. It induced earlier ovulations after introduction of males. A « breeding season " was induced by treatments using $E$, melatonin and the " male effect " in out-of-season dairy goats.

3) Efficiency of different ways of melatonin administration (P. Chemineau, unpublished results).

In order to simplify application of the different treatments without decreasing their efficiency, two other means of melatonin administration were compared : orally by daily drenching (2 mg daily at $3: 00 \mathrm{pm})$ and one sub-cutaneous 

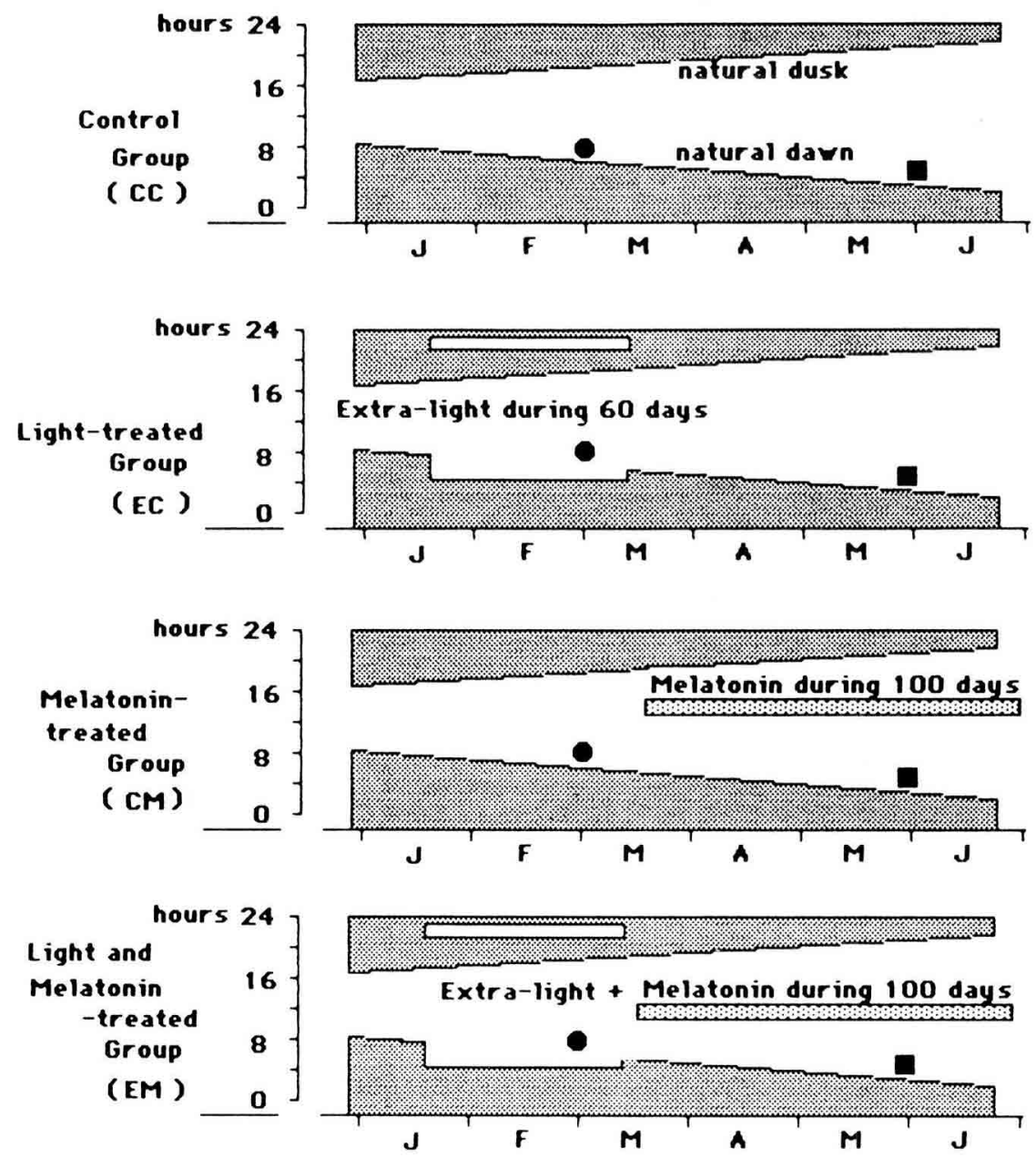

FIG. 4. - Experimental light-treatments used to control out-of-season reproductive activity in dairy goats. $\quad=$ Kidding ; $\mathbf{\square}=$ introduction of bucks ( male effect "). Adapted from Chemineau et al. (1986), by courtesy of J. Reprod. Fert.

implant inserted at the end of the photoperiodic treatment. Saanen does from melatonin-treated groups received the $\mathrm{E}$ treatment described previously. Animals (12 in each treated group and 10 in control group) were maintained in open sheds and kidded end of February to onset of March. Adult treated males were introduced on May 30 to provoke the " male effect ", as in the preceding experiment.

Melatonin-treated does ovulated earlier ( 4.4 vs 8.5 days ; $P<0.05)$ and their ovulatory activity persisted longer $(56.2$ vs 29.1 days; $P<0.01)$ than for untreated does. Does which received melatonin implants responded the same as those which were injected daily, but does which received melatonin orally had longer ovulatory activity than the two other groups $(67.2$ days; fig. 5 ). 


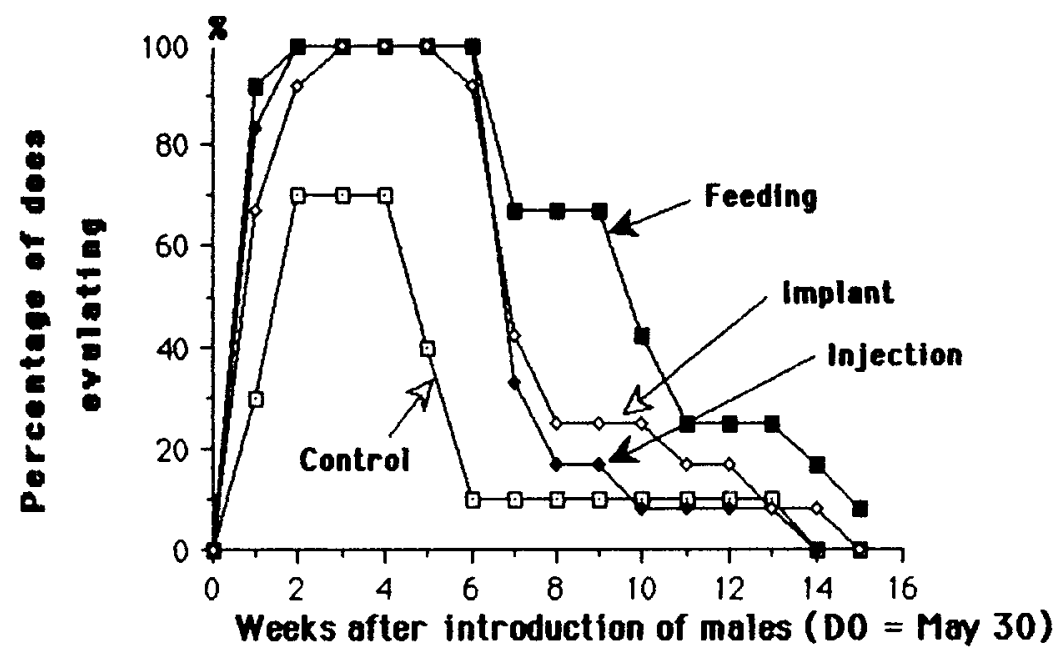

FIG. 5. - Duration of ovulatory activity in melatonin-treated and control out-of-season dairy goats. See text for detail of the three different methods of melatonin administration (P. Chemineau, unpublished results).

Melatonin delivered by implants was as effective as injection for the induction and maintenance of ovulatory activity. Under our experimental conditions, melatonin delivered by drenching was the most efficient way of administration.

4) Is the " male effect " necessary? (P. Chemineau, G. de Montigny and B. Broqua, unpublished results).

Twenty-four adult Alpine dairy does which kidded at the end of January were maintained in open sheds and received the $E$ treatment described previously. On March 03, at the end of the light treatment, they were divided into two equal groups : one group (E-melatonin implant: EMI) received the same melatonin implant as in the preceding experiment and the other group served as control (Econtrol: EC). Females were not allowed contact with males during the experiment. No ovulatory activity was detected in the EC group during the sampling period. On the contrary, 6 of 12 does from the EMI group demonstrated ovulatory activity. On the average, ovulations occurred 68 days $( \pm 11)$ after implant insertion and ovulatory activity lasted for 1.8 cycles $( \pm 0.7)$.

Male stimulation, under our experimental conditions seemed necessary to obtain maximum ovulatory response. However, the lack of response of some females could be a consequence of a limited duration of melatonin release. Indeed, it was recently demonstrated in the ewe, that the number of females responding to a melatonin treatment was strongly dependent on its duration (Nowak and Rodway, 1987). As expected from the results of experiment 1, the time for appearance of sexual activity without male stimulation when females were maintained in open sheds, was 70-80 days. As previously suggested in experiment 2, melatonin given after an $E$ treatment was necessary for the onset of ovulatory activity, as no female of EC group experienced ovulation. 
5) Milk production of melatonin-treated does (P. Chemineau and B. Broqua, unpublished results).

It was important to determine if the proposed melatonin treatments have side effects on other physiological functions of the treated females and particularly on milk production. In the preceding experiment, weekly milk production was measured in both groups, animals as a group, from 3 weeks before until 22 weeks after melatonin implant insertion. Milk production was reduced by $12 \%$ in melatonin-treated (EMI) compared to control does (EC), when the whole period was considered ( 3.08 vs $3.52 \mathrm{~kg}$ milk per day and per female). This difference was due in part to a decrease in dry matter intake ( $9 \%$ decrease) and in part to the decrease in plasma prolactin concentration, induced by the release of melatonin from the implant (data not shown). Although efficient for control of reproductive activity in does, melatonin treatment, when applied soon after kidding, sligthly reduced milk production of milking dairy does.

\section{Conclusion.}

The different treatments proposed were based on alternating periods of " $L D$ " and " $S D$ ». They resulted in :

- Advancing the first breeding season for young rams by allowing earlier production of semen. This advance increased genetic progress.

- Obtaining a "permanent non-seasonal breeder " which was able to produce large quantities of high-quality sperm-cells during a period when males of seasonal breeds of small ruminants produce low quality semen.

- Inducing and maintaining cyclical ovulatory and oestrous activities when females are normally in anoestrus and are anovulatory.

Treatments using extra-light and melatonin, do not require light-proof buildings.

Consequently, total control of reproduction in sheep and goats by photoperiodic manipulation in open sheds and melatonin treatments now appears feasible in both sexes, without need of light-proof buildings and with reduced costs.

Colloquium on "Neuroendocrine mechanisms and light control of reproduction in domestic mammals " I.N.R.A., Nouzilly, 17-18 September 1987.

Acknowledgments. - The authors want to thank Dr. F. W. Bazer for assistance with the preparation of the manuscript. Parts of these experiments were supported by an E.E.C. grant (Animal Productions Nb. 3010), by Poitou-Charentes Region and by the Artificial Insemination Centers of Roquefort Area. 
Résumé. Utilisation de la photopériode et de la mélatonine pour le contrôle de la saison de reproduction chez les ovins et caprins.

Les traitements employés en bâtiments ouverts, pour contrôler l'activité normalement saisonnière de la reproduction chez les ovins et les caprins, utilisent principalement une période de deux mois d'éclairement (E) pendant la phase photosensible (équivalent à des jours longs), suivie par trois mois de mélatonine (équivalent à des jours courts).

Chez des jeunes agneaux de race lle-de-France ou Lacaune, nés à l'automne, deux mois de $\mathrm{E}$ suivis par des jours décroissants pendant 90 jours, provoquent une avance de la $1^{\text {re }}$ saison d'activité sexuelle. Le volume testiculaire et la production spermatique maximaux des mâles sont atteints beaucoup plus tôt chez les béliers traités que chez les béliers témoins. Le remplacement de la période de jours décroissants par des implants de mélatonine entraîne un accroissement de courte durée du volume testiculaire.

Des béliers adultes de race lle-de-France, maintenus sous un régime lumineux utilisant une alternance rapide d'une période de 2 mois, ont, pendant au moins deux années consécutives, un volume testiculaire équivalent à celui observé pendant la saison sexuelle normale. Leur production spermatique constante et élevée pendant la période habituelle de repos sexuel, est alors identique à celle de la saison sexuelle.

Chez des chèvres laitières en anœstrus, l'utilisation d'un traitement lumineux (E) est nécessaire avant l'emploi de mélatonine et, de même, la mélatonine est nécessaire après un traitement lumineux. La stimulation des femelles anovulatoires par l'introduction de mâles traités (" effet mâle ") apparaît indispensable pour obtenir une réponse maximale des femelles. Deux mois de E suivis par trois mois de mélatonine (injections ou ingestions quotidiennes ou dispositif sous-cutané) améliorent la réponse à " l'effet mâle " et permettent le maintien des activités ovulatoire et œstrienne pendant plus de deux mois. Si la mélatonine est efficace pour contrôler l'activité de reproduction pendant la contre-saison, elle diminue légèrement la production laitière lorsque le traitement est appliqué peu de temps après la mise bas.

Chez les ovins et les caprins, le contrôle total de la reproduction par des manipulations photopériodiques en bâtiments ouverts et par l'emploi de la mélatonine, apparaît désormais réalisable dans les deux sexes.

\section{Références}

ARENDT J., 1986. Role of the pineal gland in seasonal reproductive function in mammals. Oxford Rev. reprod. Biol., Clarendon Press, Oxford, 8, 266-320.

ALBERIO R., 1976. Rôle de la photopériode dans le développement de la fonction de reproduction chez l'agneau Ile-de-France de la naissance à 21 mois. Thèse Doct. $3^{e}$ cycle, Univ. Paris VI, $57 \mathrm{p}$.

ALMEIDA G., PELLETIER J., 1988. Abolition of seasonal testis changes in the lle-de-France ram by short light cycles : relationship to luteinizing hormone and testosterone release. Theriogenology (Accepted for publication).

ARENDT J., SYMONS A. M., LAUD C. A., PRYDE S. J., 1983. Melatonin can induce early onset of the breeding season in ewes. J. Endocr., 97, 395-400.

CHEMINEAU P., 1987. Possibilities for using bucks to stimulate ovarian and oestrous cycles in anovulatory goats-a review. Livest. Prod. Sci, 17, 135-147.

CHEMINEAU P., NORMANT E., RAVAULT J.P., THIMONIER J., 1986. Introduction and persistence of pituitary and ovarian activity in the out-of-season lactating dairy goat after a treatment combining a skeleton photoperiod, melatonin and the male effect. J. Reprod. Fert., 78, 497-504.

COLAS G., GUÉRIN Y., BRIOIS M., ORTAVANT R., 1987. Photoperiodic control of testicular growth in the ram lamb. Anim. Reprod. Sci, 13, 255-262. 
COLAS G., GUÉRIN Y., CLANET V., SOLARI A., 1985. Influence de la durée d'éclairement sur la production et la fécondance des spermatozoïdes chez le bélier adulte lle-de-France. Reprod. Nutr. Dévelop., 25, 101-111.

DUCKER M. J., BOWMAN J. C., TEMPLE A., 1973. The effect of constant photoperiod on the expression of oestrus in the ewe. J. Reprod. Fert., Suppl., 19, 143-150.

HANSEN P. J., 1985. Photoperiodic regulation of reproduction in mammals breeding during long days versus mammals breeding during short days. Anim. Reprod. Sci., 9, 301-315.

KARSCH F. J., BITTMAN E. L., FOSTER D. L., GOODMAN R. L., LEGAN S. J., ROBINSON J. E., 1984. Neuroendocrine basis of seasonal reproduction. Recent Prog. Horm. Res., 40, 185 225.

KENNAWAY D. J., GILMORE T. A., SEAMARK R. F., 1982. Effect of melatonin feeding on serum prolactin and gonadotropin levels and the onset of seasonal oestrus cyclicity in sheep. Endocrinology, 110, 1766-1772.

KENNAWAY D. J., HOOLEY R. D., SEAMARK R. F., 1980. Effects of melatonin feeding on serum prolactin content and the onset of oestrous activity in goats. Aust. Soc. Reprod. Biol., 12 (Abstr.).

LINCOLN G. A., SHORT R. V., 1980. Seasonal breeding : nature's contraceptive. Recent Prog. Horm. Res., 36, 1-43.

MALPAUX B., ROBINSON J. E., BROWN M. B., KARSCH F. J., 1988. Importance of changing photoperiod and melatonin secretory pattern in determining the length of the breeding season in the Suffolk ewe. J. Reprod. Fert., 83 (in press).

NOWAK R., RODWAY R. G., 1987. Length of melatonin exposure and onset of ovarian activity in anoestrous ewes. J. Reprod. Fert., 80, 343-347.

OLDHAM C. M., ADAMS N. R., GHERARDI P. B., LINDSAY D. R., MACKINTOSH J. B., 1978. The influence of feed intake on sperm-producing capacity of testicular tissue in the ram. Austr. J. agric. Res., 29, 173-179.

ORTAVANT R., 1961. Réponses spermatogénétriques du Bélier à différentes durées d'éclairement. Fourth int. Congr. anim. Reprod. artif. Insem., La Haye, 2, 236-242.

ORTAVANT R., 1977. Photoperiodic regulation of reproduction in the sheep. In Symp. Management of reproduction in sheep and goats, Madison (Wisc., USA), July 24-25, 58-71.

ORTAVANT R., MAULÉON P., THIBAULT C., 1964. Photoperiodic control of gonadal and hypophyseal activity in domestic mammals. Ann. N. Y. Acad. Sci., 117, 157-193.

ORTAVANT R., PELLETIER J., RAVAULT J. P., THIMONIER J., VOLLAND-NAIL P., 1985. Photoperiod : main proximal and distal factor of the circannual cycle of reproduction in farm mammals. Oxford Rev. reprod. Biol., Clarendon Press, Oxford, 7, 305-345.

PELLETIER J., ALMEIDA G., 1987. Short light cycles induce persistent reproductive activity in lle-de-France rams. J. Reprod. Fert., Suppl., 34, 215-226.

PELLETIER J., BLANC M., DAVEAU A., GARNIER D. H., ORTAVANT R., de REVIERS M. M. TERQUI M., 1981. Mechanisms of light action in the ram : a photosensitive phase for $L H$, FSH, testosterone and testis weight? 117-134. In R. ORTAVANT, J. PELLETIER and J. P. RAVAULT, Photoperiodism and reproduction, Nouzilly (France), September 24-25 (INRA, Paris).

PELLETIER J., BRIEU V., CHESNEAU D., PISSELET C., de REVIERS M., 1985. Abolition partielle des variations saisonnières du poids testiculaire chez le bélier par diminution de la période du cycle lumineux. C. R. Acad. Sci., Paris, 301, Sér. III, 665-668.

PELLETIER J., CHEMINEAU P., THIMONIER J., VOLLAND-NAIL P., 1987. Environment and changes in reproductive activity in sheep and goats, 121-135. In P. PÉVET, Comparative physiology of environmental adaptations, vol. 3. 8th ESCP Conf., Strasbourg 1986 (Karger, Basel 1987).

PELLETIER J., THIMONIER J., 1987. The measurement of daylength in the lle-de-France ram. J. Reprod. Fert., 81, 181-186.

POULTON A. L., ENGLISH J., SYMONS A. M., ARENDT J., 1987. Changes in plasma concentrations of $\mathrm{LH}, \mathrm{FSH}$ and prolactin in ewes receiving melatonin and short-photoperiod treatments to induce early onset of breeding activity. J. Endocr., 112, 103-111.

SYMONS A. M., ARENDT, J., POULTON A. L., ENGLISH J., 1987. Induction of early seasonal sensitivity to melatonin in Suffolk-cross ewes. Chronobiology int., 4, 219-223. 
TERQUI M., THIMONIER J., 1974. Nouvelle méthode radioimmunologique rapide pour l'estimation du niveau de progestérone plasmatique. Application pour le diagnostic précoce de la gestation chez la brebis et la chèvre. C. R. Acad Sci, Paris, D 279, 1109-1112.

THIMONIER J., 1981. Control of seasonal reproduction in sheep and goats by light and hormones. J. Reprod. Fert., Suppl. 30, 33-45.

YELLON S. M., FOSTER D. L., 1985. Alternate photoperiods time puberty in the female lamb. Endocrinology, 116, 2090-2097. 